\title{
The Impact of Intellectual Capital on Firm Value: Empirical Evidence From Vietnam
}

\author{
Anh Huu Nguyen ${ }^{1} \&$ Duong Thuy Doan ${ }^{1}$ \\ ${ }^{1}$ School of Accounting and Auditing, National Economics University, Vietnam \\ Correspondence: Anh Huu Nguyen, School of Accounting and Auditing, National Economics University, Vietnam.
}

Received: March 3, 2020

Accepted: April 23, 2020

Online Published: June 28, 2020

doi:10.5430/ijfr.v11n4p74

URL: https://doi.org/10.5430/ijfr.v11n4p74

\begin{abstract}
The paper aims to investigate the impact of intellectual capital on firm value in the context of Vietnam. The research sample includes 61 manufacturing companies listed on Vietnam stock market for the period from 2013 to 2018. Three statistical methods approaches are employed to address econometric issues and to improve the accuracy of the regression coefficients include Ordinary Least Square (OLS), Random Effects Model (REM) and Fixed Effects Model (FEM). This research uses value-added intellectual capital (VAIC) to measure the intellectual capital of a firm. Value-added intellectual capital (VAIC) is considered as an effective measure by which a company uses material, financial, and intellectual capital to increase. The VAIC includes the sum of three components: Human Capital Efficiency (HCE), Structure Capital Efficiency (SCE) and Capital Employed Efficiency (CEE, including physical and financial capital). In this paper, firm value is measured by Tobin's $Q$ ratio. Some control variables such as leverage, firm size, growth rate, and state capital are used in the regression model that pointed out the impact of intellectual capital on a firm value. The empirical results show a statistically significant positive impact of value-added intellectual capital (VAIC) on a firm's profitability. This evidence provides a new insight to managers on how to improve the value of manufacturing companies listed on Vietnam stock market.
\end{abstract}

Keywords: intellectual capital, value-added intellectual capital, human capital efficiency, structure capital efficiency, capital employed efficiency, Tobin's Q, Vietnam

\section{Introduction}

Firm value and improving firm value have always received the attention of scientists and managers today. Finding the factors that can positively influence business value is important, helping to solve the fundamental problem of how to maximize shareholder benefits.

Previous studies have investigated the relationship between macro factors such as the economic environment, political environment, society, culture, customer relations, suppliers, firms. competition effect on a firm value. The results of these studies help the manager select the solution for the operation of the business to fit the context of macroeconomic change. In addition, there are studies showing relationships with internal factors such as asset structure, business location, profitability, liquidity, firm size also affect on the firm value. Managers can make the decision to influence those factors so that the business can achieve the best performance. However, there are still other internal factors affecting enterprise value that have not been considered, especially in the intangible.

Smith and Cannan (2003) stated that the wealth of nations is created from tangible assets such as labor, land and capital. These tangible factors are under law of diminishing returns, which leaves us short of insight in current knowledge economy. Scientists as well as regulators are now more focused on intangible assets, especially the participation of knowledge in the production process. Knowledge is seen as all intangible resources available to the organization, bringing relative advantage, and in combination can generate future benefits. Due to the law of increasing return, when the business invests more in knowledge based capital, the growth rate rises sharply and the market value exceeds book value. In other words, good use and management of knowledge can enhance competitive advantage in the marketplace through organizational technology, professional skills, customer relations and experience. The profit of a business is based on how to create knowledge and transform that knowledge into value. Knowledge becomes an important internal factor that affects the value of the enterprise. 
This topic builds and validates the relationship of knowledge capital to enterprise value under the control of other factors such as firm size, growth opportunities, capital structure, ownership structure. This section helps researchers and managers to have insight into enterprise valuation models and the factors that affect the value of the business. The focus is on the industrial manufacturing sector, which plays a key role in the economy as the major contributors to this sector are in GDP.

The remainder of the paper is structured as follows: Section 2 describes literature review; the next section demonstrates research methodology; results of the impact of intellectual capital on firm value are presented in Section 4. The discussion of empirical results and some recommendations are explained in Section 5. Finally, Section 6 is conclusion of the research.

\section{Literature Review}

Intellectual capital is often referred to as intangibles particularly in research literature. It is the value of a company's employee knowledge, skills, ideas, business training, which is not listed in balance sheets. In today's world, it is stated that not only the products manufactured by companies but also their intangible assets are the sources of economic value (Chen, Cheng \& Hwang, 2005). It is the reason to discuss and exam the relationship between intellectual capital and firm performance because firms are aware of the importance of these intangible assets and the present of intellectual capital in manufacture processes.

Bontis (1997) with a sample of 107 MBA students studying at Kula Lumpur and Seremban identifies three components of knowledge capital: Human Capital (HC), Structural Capital (SC), and Customer Capital (CC). Bontis, Keow and Richardson (2000) upgraded their studies by investigating the relationship between independent variables (HC, SC, CC) and dependent variable is business efficiency. Research showed that regardless of the type of business, human capital is important, the customer capital has a significant impact on the capital structure, and confirmed the development of structural capital is positively connected to the business performance. In addition, this study also shows that human capital is more powerful in the non-service industry than in the service industry. However, the limitation of this research is to be conducted using a psychometrically questionnaire. Further studies should use secondary data to measure intellectual capital.

In South Africa, Firer and Williams (2003) investigated the relationship between intellectual capital and performance of 75 companies on the Johannesburg Stock Exchange and used measures of profit, productivity and market value. The authors conclude that there is no significant relationship between intellectual capital and company performance. According to the results of this study, it seems that compared to European countries, countries in South Africa depend less on intellectual capital. This is because developing countries in South Africa use physical resources as a major source of value for their business.

Makki, Lodhi and Rohra (2009) invested the link between intellectual capital measured by VAIC model and financial performance. VAIC includes three component measures: Human Capital efficiency (HCE); Structured Capital Efficiency (SCE); capital efficiency (CEE). They suggested that the intellectual capital has significantly positive impact on capital gain of investors. Considering the relationship between knowledge capital and market value and the financial performance of enterprises. Chen et al. (2005) used secondary data from companies listed on the Taiwanese market from 1992-2002 and also the Value Added Intellectual Coefficient (VAIC) measurement method. The development of this study is to explore the relationship between knowledge capital and financial performance of enterprises in the present and in the future. The results indicated that knowledge capital has a positive impact on the market value and the current financial situation. In the future, knowledge can be considered as an indicator. The study demonstrated the different effects of the three components of VAIC on the dependent variables of market value and financial performance. The authors point out the inadequacy in the capital structure (SC), and provide evidence that the cost of investment and development (R \& D) should be added to measure this indicator. Furthermore, in the Malaysian study on the relationship between knowledge capital and corporate efficiency, Ting and Lean (2009) used the VAIC method and analyzed it in relation to the ROA. The subject found a very positive result, up to $76 \%$, on the relationship between the three components of intellectual capital and profitability

Clarke, Seng and Whiting (2011) aimed to investigate the impact of intellectual capital measured by VAIC method on firm performance measured by ROA, ROE, revenue growth, and employee productivity of Australian companies listed from 2004 to 2008. The quantitative results suggested that compared to structural capital efficiency, human capital in the last year have greater positive impact on current firm performance. Capital employed efficiency insignificantly negatively affects to all performance measurement. However, there are some missing data, leading to some problems of OLS assumptions. 
Fathi, Farahmand and Khorasani (2013) designed a model with data consisting of 49 Iranian companies listed in Tehran Stock Exchange (TSE) in three industrial sectors: vehicle, non-metallic mineral products, chemical products and material from 2001 to 2010 . The purpose is to investigate the relationship between intellectual capital measured by VAIC method and financial performance measured by ROE, ROA and growth revenue. The results showed that there is significant positive correlation between value added efficiency of capital employed and value add efficiency of human capital with ROA and ROE, but no significant relationship with growth revenue. The limitation of this study is the shortage of data (49 companies) and measurement method of financial performance which can be extended to other proxies such as Tobin's $\mathrm{Q}$ or economic value add (EVA)

Sayad and Pourmohammadi (2014) used a random sampling of 80 Iranian biotechnological production companies to examine the relationship of intellectual capital and financial performance. Biotechnology is field to provide better products using living organisms and genetic manipulation. It means the most important contributor of firm success is technology and knowledge of biochemistry and microbiology. Based on the results, human capital, structural capital and relational capital in the biotech companies all have impact on financial performance. The limitation of this study is to collect the data from questionnaire and analysis information from description and basic statistics, which may not measure the intellectual capital appropriately.

Ozkan, Cakan and Kayacan (2017) also used VAIC method to measure intellectual capital with data sample including 44 banks in Turkey from 2005 to 2014. VAIC calculate how much new value can be created per invested monetary in employed capital, human capital and structural capital. The finding of this research showed that average value added intellectual capital (VAIC) of Turkey banks in this period is 3.8868; which is lower than banks in the United Kingdom (10.8), but higher than bank in Australia (3.67) and bank operating in Malaysia (1.78). To specific, intellectual capital of Turkish bank is primarily affected by human capital efficiency coefficient (HCE); while structural capital (SCE) and capital employed (CEE) is less effective in creating value. The regression model also points out there is a positive impact between CEE and HCE on financial performance (ROA). On the other hand, SCD have no effect on financial performance in Turkey bank. The study recommended that banks operating in Turkey should use their financial and physical capital to achieve better profitability.

By contrast, Girma (2017) found out in the study using data of Ethiopian commercial banks from 2009 to 2014 that human capital efficiency (HCE) has no significant effect on the profitability (ROE and asset turnover); and has negative significant effect on ROA. The structural capital (SCE) has strong positive impact on ROE and asset turnover. It means that in Ethiopia, human capital measure by the salary and related payment of employees have no effect on profitability; and money using to make convenient environment, corporate strategy significantly affects on profitability.

Recently, Hatane, Angeline, Wedysiage and Saputra (2019) investigated the influence of intellectual capital disclosure in the annual reports on firm value measured by Tobin's $Q$, under other control variables such as firm size and leverage. The data was collected from 36 Indonesian listed companies from infrastructure, utility and transportation industry from 2013 to 2017. This period is divided into two stages: before and after Joko Widodo was elected in July 2014, which was marked as the beginning of a new, more democratic era of Indonesian. The results showed that before Joko Widodo's era, there is no impact from intellectual capital disclosure on firm value. The limitation of this study is just focusing on the content analysis of intellectual capital disclosure in the annual reports, not the quality of intellectual capital performance.

Samad, Yusoff and Ismail (2019) focus on three types of intellectual capital: human capital, structural capital and relational capital to identify the role of intellectual capital on the effectiveness of social enterprise. The data was collected randomly from 210 social enterprises in Malaysia in 2010 with the effectiveness ratio is measured by self-constructed financial viability index. It presents the ability of an organization to sustain in term of cost efficiency, fund availability. It concluded that compared to structural and relational capital, human capital was the key contributor in increasing the financial viability. The limitation of this study is just focusing on solely financial aspects to measure the effectiveness of social enterprise. The non-financial aspects also need to be considered as well.

From the literature review, some conclusions have been pointed out as follows:

Firstly, many authors in the world have studied the factors affecting the production and business efficiency of enterprises such as Santos and Brito (2012), however, these factors have not been found yet and knowledge capital is one of those potential factors. The study of the impact of intellectual capital on financial efficiency is still limited. 
Secondly, it can be seen that intellectual capital is receiving the attention of researchers. On the other hand, these studies are carried out in most dynamic economies with outstanding advantages in working environment or quality human resources such as Australia (Clarke et al., 2011) or Taiwan (Chen et al., 2005). It is not appropriate to take the research results from economies of uneven nature with Vietnam to apply to the enterprise management process in our country. Furthermore, invisible capital sources such as human capital, intellectual property rights are a new topic in Vietnam.

Thirdly, the conclusions about the influence of intellectual capital on the value of enterprises also cause many concerns for policy makers, economic managers, enterprises and related objects. There are a lot of studies showing the positive impact between knowledge and business performance such as Chen et al. (2005), Clarke et al. (2011), Sayad and Pourmohammadi (2014), Ozkan et al. (2017) but also some studies show the opposite effect as the topic of Girma (2017) or points out that there is no relationship between IC and performance (Firer and Williams, 2003), (Hatane et al., 2019). The inconsistency in research results is due to specific characteristics of the sample, study time and specific characteristics of each economy.

In summary, studies on the influence of intellectual capital on financial performance of Vietnamese enterprises are still limited in terms of both quantity and sample size and study time. Recognizing the urgency of the research topic along with exploiting the above gaps.

\section{Research Methodology}

\subsection{Research Sample}

This study investigates the impact of intellectual capital on firm value of listed Vietnamese firms during the period of time from 2013 to 2018. The data is collected from manufacturing listed financial reports in Ho Chi Minh Stock Exchange and Hanoi Stock Exchange. Firms which do not have all required ratio during the whole period are excluded. There are 123 manufacturing listed firms on Ho Chi Minh Stock Exchange and 116 firms on Hanoi Stock Exchange meet the requirement. However, according to Clarke et al. (2011) for developing market like Vietnam, the awareness of intellectual capital is currently not high. Most of firms do not focus on knowledge capital yet. Therefore, using the whole manufacturing firm listed on both stock exchange may cause the poor results. The sample is zipped to 32 listed firms on Ho Chi Minh Stock Exchange and 29 listed firms on Hanoi Stock Exchange that have market capitalization value above 1000 biliion VND. The study continues using OLS, FEM, REM to test the relationship between intellectual capital and firm value.

\subsection{Model Specification}

$$
\begin{aligned}
\text { Tobin's } \mathrm{Q}_{\mathrm{i}, \mathrm{t}}= & \beta_{0}+\beta_{1} * \mathrm{HCE}_{\mathrm{i}, \mathrm{t}}+\beta_{2} * \mathrm{SCE}_{\mathrm{i}, \mathrm{t}}+\beta_{3} * \mathrm{CEE}_{\mathrm{i}, \mathrm{t}}+\beta_{4} * \mathrm{LEV}_{\mathrm{i}, \mathrm{t}}+\beta_{5} * \mathrm{SIZE}_{\mathrm{i}, \mathrm{t}} \\
& +\beta_{6} * \mathrm{GROWTH}_{\mathrm{i}, \mathrm{t}}+\beta_{7} * \mathrm{STATE}_{\mathrm{i}, \mathrm{t}}+\varepsilon_{\mathrm{i}}
\end{aligned}
$$

where:

Tobin's Q: This ratio is more than zero, indicating that the business is profitable. The higher the ratio, the higher the efficiency of business operation and vice versa. The study of McGuire, Sundgren and Schneeweis (1988); Russo and Fouts (1997); Clarkson, Li, Richardson and Vasvari (2008); Vijayakumaran (2019) used Tobin's Q as a measure of a firm value. In this paper, we do not use return on assets (ROA) to measure firm value like the research of Wu and Wu (2018) or Ali, Hussin and Ghani (2019); Chabachib, Hersugondo, Ardiana and Pamungkas (2020) measure the firm's profitability by return on assets (ROA) and return on equity (ROE).

VAIC is considered as an effective measure by which a company uses material, financial, and intellectual capital to increase developed value-added intellectual Capital (VAIC). The VAIC includes the sum of three components: Human Capital Efficiency (HCE), Structure Capital Efficiency (SCE) and Capital employed Efficiency (CEE, including physical and financial capital).

Human Capital Effect (HCE): Human capital includes the skills, experience, productivity, knowledge and suitability of employees in the workplace. $\mathrm{HCE}_{\mathrm{i}, \mathrm{t}}=\mathrm{VA} / \mathrm{HC}$. In which, VA: The net value generated by a business over a year is expressed as: $\mathrm{VA}=\mathrm{NI}+\mathrm{T}+\mathrm{DP}+\mathrm{I}+\mathrm{W}$ (with NI: net income after tax; I: interest expense, W: worker's wage). HC measures labor cost.

Structured Capital Efficiency (SCE): elements of capital structure including proprietary computer systems, databases, strategies, formulas or patents, information systems, production processes, the results or the products the business has created over time. $\mathrm{SCE}_{\mathrm{i}, \mathrm{t}}=\mathrm{SC} / \mathrm{VA}$. Where, SC: Capital structure, calculated by the formula: $\mathrm{SC}=\mathrm{VA}-\mathrm{HC}$. VA: The net value created by the business for one year. 
The Capital Employed Efficiency CEE) is the economic term reflecting the level of exploitation and use of capital of enterprises in production and business activities in order to create maximum value with minimum cost. This ratio presents a dollar spent on using capital generates how much value for the company. To achieve the objective of maximizing the return or maximizing the value of an enterprise, enterprises must seek measures to exploit and use the internal resources thoroughly and outside the firm. Therefore, the efficiency of using capital of enterprises must be put on the top. $\mathrm{CEE}_{\mathrm{i}, \mathrm{t}}=\mathrm{VA} / \mathrm{CE}$. Where, VA: The net value created by the business for one year; CE: Financial and material capital, calculated as (Total Assets - Intangible Assets).

Leverage is the ratio of debt to total assets in a company's capital structure. Studies by Ghosh, Nag and Sirmans (2000), Berger and Patti (2006) show that the relationship between leverage and financial performance is positive. Meanwhile, studies by Gleason, Knowles and Mathur (2000), Simerly and Li (2000) Zeitun and Tian (2007) show that negative business leverages on financial performance.

Company size is considered to be an important determinant of corporate profitability (Babalola \& Abiola, 2013). Hussain and Malik (2011) have shown that the size of the business is positively correlated with enterprise profitability. However, some studies have shown the opposite the research results of Allayannis and Weston (2001). SIZE $_{\mathrm{i}, \mathrm{t}}=$ LOG (Total Assets).

Growth rates and business performance were considered positive for each other through studies by Thomas, Bromiley and Hendrickx (2000), Zeitun and Tian (2007). GROWTH $\mathrm{H}_{\mathrm{i}, \mathrm{t}}=\left(\mathrm{Sales}_{\mathrm{t}}-\mathrm{Sales}_{\mathrm{t}-1}\right) / \mathrm{Sales}_{\mathrm{t}-1 .}$.

State capital is the ratio of state capital in total capital of a firm. At present, SOEs in Vietnam are entering the equitization process. This not only enhances the supervision of shareholders but also increases the resources of society to business. The equitization is the change in the nature of management to enhance the responsibility of shareholders with the operation of the business. With state owned enterprises, property and resources are managed and owned by the state so that the efficiency of the employees is not high. In these enterprises there are often negative as corrupt, not utilizing talents. A study of ownership by Dewenter and Malatesta (2001) indicates that the value of private firms is often higher than that of SOEs as a result of business cycles. STATE $\mathrm{E}_{\mathrm{i}, \mathrm{t}}=\mathrm{State}_{\mathrm{Capital} / \mathrm{Total}}$ Capital.

\section{Empirical Results}

A statistic description is presented in order to analyze the basic characteristics of the variables. Table 1 contains such information.

Table 1. Descriptive statistics

\begin{tabular}{llllll}
\hline Variables & Observation & Mean & Standard Deviation & Min & Max \\
\hline TOBIN Q & 366 & 0,0456 & 0,05148 & $-0,2819$ & 0,7838 \\
\hline VAIC & 366 & 3,3786 & 7,3135 & $-2,0546$ & 52,9112 \\
\hline HCE & 366 & 2,9806 & 6,0503 & $-5,0775$ & 38,6546 \\
\hline SCE & 366 & 0,6716 & 0,3926 & $-4,7479$ & 1,5609 \\
\hline CEE & 366 & 0,2372 & 0,6941 & $-0,1219$ & 2,1421 \\
\hline LEV & 366 & 0,6841 & 0,2209 & 0,10688 & 0,9017 \\
\hline SIZE & 366 & 11,0332 & 0,5667 & 1,9008 & 14,1563 \\
\hline GROWTH & 366 & 0,1942 & 0,2631 & $-0,5068$ & 9,8057 \\
\hline STATE & 366 & 0,1925 & 0,2699 & 0 & 0,9998 \\
\hline
\end{tabular}

The Tobin Q indicates the relationship between the ratio of net profit to total assets and the average value of $4.56 \%$. However, there is a huge difference, with a minimum value of $-0,2819$ and a maximum value of 0,7838 . The mean of value added intellectual capital (VAIC) is 3,3786 and the significant difference between observations (standard deviation is 7,3135) is due to the fact that the use of knowledge capital in different occupations is different. GROWTH variable has a range from $-0,5068$ to 9,8057 . This indicates that the data set include of firms in a variety state of financial development. STATE variable also has the figure between 0 and 0,9998 which suggest that the data 
set contains both state own and private entities. The inclusion of different firms with different characteristic is crucial as it eliminates the threat of selection bias.

A simple correlation matrix can be utilized in order to examine the raw relationship between the variables. Theoretically, we expect the raw correlation to be complied with the discussed assumptions about the variables relationship. The matrix correlation will be presented in table 2 .

Table 2 shows prominent result as a positive relationship can be found between the variables of interest (VAIC, SCE, CEE, HCE) and the dependent variable of Tobin q. This is a strict compliance to the above-assumed hypotheses. This result supports the confident on data set acquired and method used. In contrast, the control variables (LEV, SIZE, STATE) show a negative correlation with the dependent variable. Intuitively, we expect the firm value will increase with positively increase with respect to the firm's leverage, size. This negative sign can be caused by the data set's unique characteristics, which reflect others, external factors such as business environment, regulations. However, to precisely capture the effect of these variables on Tobin's Q, a regression model is required. Further discussion about this will be the control variables' sign will be positioned below after a set of regression results are generated.

Table 2. Correlation matrix

\begin{tabular}{|c|c|c|c|c|c|c|c|c|c|}
\hline & LEV & SIZE & GROWTH & STATE & HCE & SCE & CEE & VAIC & $\bar{Q}$ \\
\hline LEV & 1,0000 & 0,3716 & 0,0151 & 0,0728 & $-0,1685$ & $-0,2525$ & $-0,1760$ & $-0,3476$ & $-0,1996$ \\
\hline SIZE & & 1,0000 & 0,0114 & 0,0117 & 0,1801 & 0,1878 & $-0,1341$ & 0,7552 & $-0,0204$ \\
\hline GROWTH & & & 1,0000 & $-0,0589$ & 0,0774 & 0,0548 & $-0,1955$ & 0,4672 & $-0,0257$ \\
\hline STATE & & & & 1,0000 & 0,0122 & $-0,0922$ & 0,1021 & 0,0925 & $-0,0650$ \\
\hline HCE & & & & & 1,0000 & 0,3169 & 0,4122 & 0,4582 & 0,1458 \\
\hline SCE & & & & & & 1,0000 & 0,6749 & 0,3678 & 0,1169 \\
\hline CEE & & & & & & & 1,0000 & 0,4712 & 0,3460 \\
\hline VAIC & & & & & & & & 1,0000 & 0,1436 \\
\hline Q & & & & & & & & & 1,0000 \\
\hline
\end{tabular}

Table 3. Regression results






\begin{tabular}{lll}
\hline Test & P-value $=3 . e-226$ & \\
\hline Hausman & & $\begin{array}{l}\text { Chi2 }(6)=88.02 \\
\text { Prob }>\text { chi2 }=0,0000\end{array}$ \\
\hline xttest3/xttest0 & & \\
& & Chi2 $(179)=6.7 \mathrm{e}+08$ \\
Prob $>$ chi2 $=0,0000$ & \\
\hline
\end{tabular}

Note: the estimation was run using robust standard deviation. P-values are reported in parentheses. The result in column 1 is a normal OLS regression while column 2 and 3 show results with the use of fixed and random effect respectively.

With the Hausman test, the Fixed Effect Model (FEM) result is used to analysis the impact of intellectual capital on firm value.

Firstly, the relationship between human capital efficiency (HCE) and financial performance is the positive. To specify, $\beta 1=0,0412$ shows that when human capital efficiency increases by 1 unit, the financial efficiency increases by 0,0412 units and this result is statistically significant at the level of 5\%. This confirms the effectiveness of human capital has a positive effect on the financial performance of manufacturing enterprises listed on the Ho Chi Minh Stock Exchange and Hanoi Stock Exchange, period 2013-2018. This result supports the views of Chen et al. (2005), Clarke et al. (2011), but is different from study of Firer and Williams (2003) in their African market studies. They stated there is no relationship between HCE and Tobin's Q. Knowing how to use and improve the quality of human resources is one of the keys to the success of a business, especially those in the non-manufacturing sector. Machinery may be outdated but human capacity will develop if it is working in a good environment.

Secondly, the efficiency of capital structure has the same effect on the return on assets and this result is statistically significant with $\mathrm{p}$-value $=0,005$. The regression coefficient 0,0869 indicates that when SCE increases by 1 , the Tobin's $Q$ increases by 0,0869 . This confirms the effect of structured capital has a positive effect on the financial performance of manufacturing listed firms on the Ho Chi Minh City Stock Exchange and Hanoi Stock Exchange with the period 2013-2018, similar to Hong Kong's experimental evidence of Chan (2009b). In contrast to this conclusion, Shiu (2006b), Ting and Lean (2009) point to the negative relationship of the efficiency of using structured capital to the return on assets. Structured capital represents the core values of the internal machinery of an enterprise. An economic organization that builds its foundations for a firm corporate culture will gain many advantages in the business process and will stand up to difficulties in different contexts of the economy.

Thirdly, capital employed efficiency has the same effect and among the three factors of VAIC, this factor has the strongest impact on Tobin's Q. With $\beta 3=0,2628$, when the capital efficiency increased by 1 unit, the financial performance increased by 0,2628 units. This is consistent with the empirical evidence of Clarke et al. (2011), which shows a similar correlation between these two factors. However, with a significance level of 5\%, this result is not statistically significant, which means that the capital employed efficiency has a positive effect on the financial performance of Vietnamese manufacturing listed firms is not supported.

Considering the significance level of $5 \%$, the effective use of structured capital (SCE) has the strongest impact on the financial performance of enterprises. This result is different from the study by Ting and Lean (2009) and Singh and Narwal (2016), showing that CEE is the most powerful component of Tobin's Q, followed by HCE and SCE respectively. It can be seen that when referring to this intangible capital in Vietnam, manufacturing enterprises use the resources of the organization as corporate culture or management system more efficiently than using the resources of each individual in the company. This implies that manufacturing enterprises listed on the Ho Chi Minh Stock Exchange and Hanoi Stock Exchange do not have appropriate human resource management methods to enhance the qualities such as creativity, dynamism or individual satisfaction.

Fourthly, the relationship between GROWTH and Tobin's Q show a positive sign with the coefficient of $\beta_{4}=0,0069$. This indicates that when the firm's speed of growth increase by 1 unit the firm financial efficiency will increase 0,0069 unit. This is consistence with Zeitun and Tian (2007). However, with the significant level of 5\%, this result is statistically insignificant.

Fifthly, the negative relationship between state ownership and Tobin's Q, which derived from the regression result, support the claim of some previous research but contrast with Le and Chizema (2011). The coefficient $\beta_{5}=-0,0255$ shows that when STATE variable increase by 1 unit, Tobin's $Q$ will decrease by 0,0255 unit. With respect to Vietnam business environment, this result is understandable. State own enterprise might consider the subsidize assets 
as a safety net and neglect improving business result. Therefore, it is essential for government to decrease the percentage of state-ownership assets of firms in order to encourage competition and seft-improvement.

Finally, in this model, the LEV variable has the same effect on Tobin's Q, the SIZE variable has a negative effect on Tobin's Q. This suggests that as the firm expands in size, the financial efficiency of the company decrease. This is understandable that as the company grows, the amount of assets increases as well and if the management cannot adapt accordingly, it will be challenging to utilized newfound, new-earn assets. This suggest that, Vietnam management in general are still young and experience. However, this might not be the case for developed countries, as the manager forces are more familiar with large asset management. To fully understand this phenomenon, further research is required.

\section{Discussion and Recommendations}

\subsection{Discussion}

Through the empirical research using 32 listed manufacturing firms on Ho Chi Minh Stock Exchange and 29 listed manufacturing firms on Hanoi Stock Exchange in the period between 2013-2018, and using fix effect model, the following results are derived.

Firstly, the result shows a positive relationship between value-added intellectual capital (VAIC) and value of a firm (Tobin's Q) have a positive and significant relationship. This finding perfectly comply with Vietnam economic situation period of 2013-2018 and research conducted by Gan and Saleh (2008), Clarke et al. (2011), Singh and Narwal (2016). It can be said that the more efficient use of intellectual capital, the higher the profitability of the business. This suggests that investors, businesses and regulators should have a broad overview, especially focus on knowledge capital when evaluating the value of an economic organization.

Secondly, three components of VAIC (SCE, HCE, CEE) have different effect on the firm value. CCE has a larger positive effect compared to SCE and CEE. This result reinforces empirical evidence from Gan and Saleh (2008), Clarke et al. (2011), Chan (2009b) but different from the Hejazi, Ghanbari and Alipour (2016), Ting and Lean (2009). It can be seen that the use of structured capital is more effective than human capital, implying that manufacturing companies listed on the Vietnamese stock market do not know how to utilize the capabilities of their staffs. At the same time, this result also provides suggestions for evaluating a company's value. Closely related to the intellectual economy, investors should not rely solely on financial information but rather on non-financial information to gain board insights about the business.

\subsection{Recommendations}

From the regression model, we can see that the factor of intellectual capital plays an integral role in determining a firm financial efficiency. However, it is argued that, Vietnam firms still haven't fully understood and utilized its value. From the presented result, the author wants to make some recommendations with the aim of improving not only the quality but also the contribution of intellectual capital in developing financial efficiency of a firm and the economy in general.

Firstly, in order to increase the knowledge of investors about knowledge capital, enterprises need to disclose information about the knowledge capital of their own units, except for elements that need to be kept confidential. Abundance of intellectual capital should be reflected in the annual report or other media of the business to investors as well as other stakeholders to create a positive effect on the market value of the business. Information disclosure should emphasize the current benefits and potential growth of that intellectual capital, rather than merely introducing what the company owns.

Secondly, for those businesses that have not accumulated much intellectual capital, they need to supplement and accumulate capital to increase the value of enterprises in the market as well as catch up with the development trend of the economy. The time to build and accumulate capital will be shortened if the company takes advantage of opportunities and learning experiences from its competitors or their predecessors._On the other hand, development needs to be consistent with the structure or characteristics of organizational structure, strategy, scale, process ... requires the building and accumulation of all components in the enterprise, more specifically, human resources.

The authors use a knowledge-based approach consisting of three main components: human capital, structured capital, and utilized capital. Despite the low correlation between the efficiency of using these factors and the effectiveness of corporation financial activities. These results, together with comparative analysis and comparisons, are similar to those of other studies in the world.

In order to improve the efficiency of the use of intellectual capital, enterprises should pay attention to each factor of increasing intellectual capital. Specifically: 


\section{Improving effectiveness of human capital}

The study found that the mean HCE was 2,98 , with a range from $-5,0775$ to 38,6546 , indicating a very large difference (about 43 units) in the effectiveness of using human capital in enterprises.

Human resources are the most important assets that exist in a company. It represents the human element in an organization that, thanks to a combination of intelligence, skill, knowledge, aptitude and expertise, gives the organization a special character. This contributes to it for the production process and generates profits for the enterprise, thereby improving the performance of that enterprise.

Efficiency in the use of resources plays an important role in determining the strength of the organization. In the current economy, measuring human capital efficiency has become an essential issue for companies as it can help them get the right perspective on human capital. An effective and appropriate measurement tool, therefore, can provide businesses with the information they need to improve their contribution to the organization's success.

With globalization, businesses are increasingly facing global competition. Knowledge, expertise and labor productivity which seen as an important resource strategy is essential to build and maintain their competitive advantage. Realistically, Vietnam's labor productivity is very low, only 1/18 of Singapore, 1/6,5 Malaysia, 1/3 Thailand and China. In ASEAN region, current Vietnamese labor productivity is only higher than that of Myanmar and Cambodia, and is close to that of Laos. In order to improve the productivity and efficiency of employees, organizations should commit to regular training, staff development, and a work environment that is beneficial to them. The authors would like to propose some policies to increase labor productivity as follows:

Renew the role, function and improve the financial performance of the Government. Emphasize the role of the government to increase productivity, transform growth patterns, help the economy overcome the middle-income trap. Accordingly, there should be a reform of administrative procedures, the establishment of e-government to enhance the role of the government.

Raise awareness about the contribution of labor productivity in the financial performance of enterprises and the management apparatus, managers and workers. Labor productivity improves the competitiveness of enterprises in the long run. In order to achieve the effect of this advantage, the work of ideological education and propaganda of socio-political organizations in enterprises is very important. Applying measures to raise the sense of observance of discipline and regulations in labor.

Enterprises should introduce policies on human resources such as: management and use of human resources; recruiting, training and creating conditions for laborers to study and develop; appropriate salary policy. The Government should support and encourage enterprises, individuals and organizations to apply modern science and technology which thereby improving the quality of their products and services.

Renewing the education system in the direction of enhancing international integration in terms of contents, teaching methods, examinations and educational management. Building and developing the information system, forecasting the supply and demand of human resources to each sector / area of the economy. Training human resources in a professional manner, fully equipped for full knowledge of both theory and practice.

\section{Improving the effectiveness of structured capital}

As a result of the model, the effect of structured capital has had a positive impact on the financial performance measured by accounting methods of manufacturing enterprises on Ho Chi Minh Stock Exchange and Hanoi Stock Exchange in the period 2013-2018. The impact of SCE is greater than HCE.

In order to develop a structured capital, an enterprise can invest by developing computer systems, databases, software, strategies, processes, supply chains, etc. The development of components Structural capital requires a long time and is costly. Businesses need to set long-term goals for the program along with knowing how to capitalize on the competitor's experience to shorten this process. Specifically:

Strengthen the system of exchange and processing of information inside and outside the enterprise. In the 4.0 economies, information becomes very valuable assets in the business. To achieve financial efficiency as well as strong development in the market, enterprises need to perfect the information system to optimize the most. The precise information on the market supply of goods, technology, buyers and competitors in the market really needed. In addition, businesses should leverage information on successful experiences or learn from the failures of other domestic and international businesses as well as information on changes in economic policies. On the other hand, it is necessary to improve the information exchange system within the enterprise. In order to carry out production and business activities, there must be communication between departments as well as the employees in the enterprise, which require information exchange within the company. Therefore, the efficiency of the business activities of the 
enterprise depends very much on the information exchange system of enterprises. The process of transferring information from one person to another, from one department to another, creates work coordination, mutual understanding, complementary experiences, knowledge and understanding of all. Facilitating each other quickly, accurately and precisely is the necessary conditions for enterprises to effectively carry out their production and business activities.

Businesses also need to pay attention to two issues: the choice of suppliers and the preservation of materials. In the manufacturing business, the cost of the product greatly influences the choice of raw materials and inputs. Thus the relationship between the business and the supplier appears. The quality assurance, the quantity and the price of the inputs of the business depends on the nature of the factors and of the supplier and their behavior. Enterprises also need to minimize the cost of using inputs contributing to improving financial performance.

Businesses need to identify and create a unique environment. The working environment includes exchanges, emotions, relationships, sense of responsibility and the spirit of collaboration. The cultural environment is of special significance and has a decisive impact on the employability of the workforce and other factors of the enterprise. Successful businesses are businesses that focus on building, creating a separate cultural environment with other businesses. Corporate culture creates a great competitive advantage for businesses, which directly affects the formulation of strategic goals and policies in the business of the business, and facilitates the successful implementation of the business strategy chosen by the business.

\section{Improving effectiveness of utilizing tangible assets}

The efficiency of capital utilization reflects the level of exploitation, use and management of capital, making the maximum return on capital to maximize profits. It also reflects the relationship between the output and the input of the production process through the monetary measure or, in other words, the correlation between the cost result and the return for performance of manufacturing business. Therefore, raising the efficiency of capital use is a condition for enterprises to develop sustainably. The author, therefore, proposed the following recommendations:

The State and authorities at all levels should have policies to support at difficult times, stimulate consumption and promote enterprises to increase production. The State and banks should make interest rate cuts so that loans can be made to businesses more conveniently and efficiently. Authorities need to make further efforts in the equitization and divestment of state enterprises in these enterprises in order to improve the profitability of Vietnamese manufacturing enterprises.

Managers must have the understanding and strategic vision of their business and make the right decisions for business development. Enterprises should build a roadmap for the use of capital for each stage and business area. Enterprises need to exploit capital thoroughly and prevent idle or wasted capital. Enterprises need to capture the capital, the time of capital so that achieving optimal profit with lowest cost. Businesses need to devise specific business strategies that are appropriate to their financial position, planning and allocating them appropriately. In addition, businesses must always mobilize capital, invest more to expand production scale and field of operation. Additional sources of capital that can be mobilized include self-financing, bank loans, other loans, joint ventures, etc. The selection of funds is very important and must be based on the principle of effectiveness economy.

Businesses need to know and apply marketing methods well, there should be a team working in charge of market research to get full information about the demand as well as the evolution of the market. On that basis, it is possible to change the business plan as well as the product and determine the reasonable price.

\section{Limitations and Conclusion}

There are some limitations to this study. Firstly, the study limited intellectual capital in three categories by using VAIC method, including its components: Human Capital efficiency (HCE); Structured Capital Efficiency (SCE); capital employed efficiency (CEE). However, there are other methods to measure intellectual capital such as business renewal, relation capital or development capital. Secondly, the control variables of financial performance are not limited to only leverage, firm size, growth rate, and state capital. Therefore, in further research, other factors should be extended such as corporate governance, cash flow.

In conclusion, this paper investigates the impact of intellectual capital on firm value with the research sample of 61 manufacturing companies listed on Vietnam stock market for the period from 2013 to 2018. The empirical results show all three components of value-added intellectual capital include Human Capital Efficiency (HCE), Structure Capital Efficiency (SCE) and Capital Employed Efficiency (CEE) have a statistically significant effect on the firm value that measured by Tobin's Q ratio. Based on the empirical results of this research, we have made some recommendations for business managers, investors, and other stakeholders to make reasonable decision making to 
enhance the firm value through improving three elements of value-added intellectual capital, which is proxy for a firm value in the context of Vietnam.

\section{Acknowledgements}

This research is funded by the National Economics University (NEU), Hanoi, Vietnam. The authors thank anonymous referees for their contributions and the NEU for funding this research.

\section{References}

Ali, M. M., Hussin, N. N. A. N., \& Ghani, E. K. (2019). Liquidity, growth and profitability of non-financial public listed Malaysia: a Malaysian evidence. International Journal of Financial Research, 10(3), 194-202. https://doi.org/10.5430/ijfr.v10n3p194

Allayannis, G., \& Weston, J. P. (2001). The use of foreign currency derivatives and firm market value. Review of Financial Studies, 14(1), 243-276.

Babalola, Y. A., \& Abiola, F. R. (2013). Financial ratio analysis of firms: a tool for decision making. International Journal of Management Sciences, 1(4), 132-137.

Berger, A. N., \& Patti, E. B. (2006). Capital structure and firm performance: a new approach to testing agency theory and an application to the banking industry. Journal of Banking \& Finance, 30(4), 1065-1102. https://doi.org/10.1016/j.jbankfin.2005.05.015

Bontis, N. (1997). Royal Bank invests in knowledge-based industries. Knowledge Inc., 2(8), 1-4.

Bontis, N., Keow, W. C. C., \& Richardson, S. (2000). Intellectual capital and business performance in Malaysian industry. Journal of Intellectual Capital, 1(1), 85-100. https://doi.org/10.1108/14691930010324188

Chabachib, M., Hersugondo, H., Ardiana, E., \& Pamungkas, I. D. (2020). Analysis of company characteristics of firm values: profitability as intervening variables. International Journal of Financial Research, 11(1), 60-70. https://doi.org/10.5430/ijfr.v11n1p60

Chan, K. H. (2009b). Impact of intellectual capital on organisational performance: an empirical study of companies in the Hang Seng index (part 2). The Learning Organisation, 16(1), 22-39. https://doi.org/10.1108/09696470910927650

Chen, M. C., Cheng, S. J., \& Hwang, Y. (2005). An empirical investigation of the relationship between intellectual capital and firms' market value and financial Performance. Journal of Intellectual Capital, 6(2), 159-176. https://doi.org/10.1108/14691930510592771

Clarke, M., Seng, D., \& Whiting, R. H. (2011). Intellectual capital and firm performance in Australia. Journal of Intellectual Capital, 12(4), 505-530. https://doi.org/10.1108/14691931111181706

Clarkson, P. M., Li, Y., Richardson, G. D., \& Vasvari, F. P. (2008). Revisiting the relation between environmental performance and environmental disclosure: an empirical analysis. Accounting, Organizations and Society, 33(4-5), 303-327. https://doi.org/10.1016/j.aos.2007.05.003

Dewenter, K. L., \& Malatesta, P. H. (2001). State-owned and privately-owned firm: an empirical analysis of profitability, Leverage, and labor intensity. American Economic Review, 91(1), 320-334. https://doi.org/10.1257/aer.91.1.320

Fathi, S., Farahmand, S., \& Khorasani, M. (2013), Impact of Intellectual Capital on Financial Performance, International Journal of Academic Research in Economics and Management Sciences, 2(1), 6-17.

Firer, S., \& Williams, S. M. (2003). Intellectual capital and traditional measures of corporate performance. Journal of Intellectual Capital, 4(3), 348-360. https://doi.org/10.1108/14691930310487806

Gan, K., \& Saleh, Z. (2008). Intellectual capital and corporate performance of technology-intensive companies: Malaysia evidence. Asian Journal of Business and Accounting, 1(1), 113-130. Retrieved from https://ajba.um.edu.my/article/view/2197

Ghosh, C., Nag, R., \& Sirmans, C. F. (2000). The pricing of seasoned equity offerings: evidence from REITs. Real Estate Economics, 28(3), 363-384. https://doi.org/10.1111/1540-6229.00805

Girma, B. (2017). Intellectual capital efficiency and its impact on financial performances of Ethiopian commercial banks. Research Journal of Finance and Accounting, 8(8), 17-31. 
Gleason, K. C., Knowles, L. L., \& Mathur, I. (2000). The interrelationship between culture, capital structure, and performance: evidence from European retailers. Journal of Business Research, 50(2), 185-191. https://doi.org/10.1016/S0148-2963(99)00031-4

Hatane, S., Angeline, C., Wedysiage, M., \& Saputra, V. (2019). Intellectual Capital Disclosure and Firm Value: Does Jokowi's Era Matter?. Advances in Economics, Business and Management Research, 69, 80-86. https://doi.org/10.2991/teams-18.2019.15

Hejazi, R., Ghanbari, M., \& Alipour, M. (2016). Intellectual, human and structural capital effects on firm performance as measured by Tobin's Q. Knowledge and Process Management, 23(4), 259-273. https://doi.org/10.1002/kpm.1529

Hussain, S., \& Malik, S. (2011). Inflation and economic growth: evidence from Pakistan. International Journal of Economics and Finance, 3(5), 32-54. 10.5539/ijef.v3n5p262

Le, T., \& Chizema, A. (2011). State ownership and firm performance: evidence from the Chinese listed firms. Organizations and Markets in Emerging Economics, 2(2), 72-90.

Makki, M. A. M., Lodhi, S. A., \& Rohra, C. L. (2009). Impact of intellectual capital on shareholders earning. Australian Journal of Basic and Applied Sciences, 3(4), 3386-3398. Retrieved from https://www.researchgate.net/publication/260176867

McGuire, J. B., Sundgren, A., \& Schneeweis, T. (1988). Corporate social responsibility and firm financial performance. Academy of Management Journal, 31, 854-872. http://doi.org/10.2307/256342

Ozkan, N., Cakan, S., \& Kayacan, M. (2017). Intellectual capital and financial performance: A study of the Turkish Banking Sector. Borsa Istanbul Review, 17(3), 190-198. https://doi.org/10.1016/j.bir.2016.03.001

Russo, M. V., \& Fouts, P. A. (1997). A resource-based perspective on corporate environmental performance and profitability. Academy of Management Journal, 40, 534-559. http://doi.org/10.2307/257052

Samad, N. H. B. A., Yusoff, N. M., \& Ismail, R. F. (2019). Effectiveness of social enterprise in managing intellectual capital. International Journal of Financial Research, 10(3), 280-290. https://doi.org/10.5430/ijfr.v10n3p280

Santos, J. B., \& Brito, L. A. L. (2012). Toward a subjective measurement model for firm performance. BAR, Rio de Janeiro, 9(SPE), 95-117. https://doi.org/10.1590/S1807-76922012000500007

Sayad, A., \& Pourmohammadi, R. (2014). Evaluating the relationship between intellectual capital and financial performance in Iranian biotechnological production companies. European Journal of Experimental Biology, $4(1), 168-173$.

Shiu, H. J. (2006). The application of the value added intellectual coefficient to measure corporate performance: evidence from technological firms. International Journal of Management, 23(2), 356-365.

Simerly, R. L., \& Li, M. (2000). Environmental dynamism, capital structure and performance: a theoretical integration and an empirical test. Strategic Management, 21(1), 31-49. https://doi.org/10.1002/(SICI)1097-0266(200001)21:1<31::AID-SMJ76>3.0.CO;2-T

Singh, R. D., \& Narwal, K. P. (2016). An examination of the relationship between intellectual capial efficiency and financial performance. South Asian Journal of Management, 23(3), 78-101.

Smith, A., \& Cannan, E. (2003). The wealth of nations. New York, N.Y: Bantam Classic

Thomas, H. B., Bromiley, P., \& Hendrickx, M. (2000). The free cash flow hypothesis for sales growth and firm performance. Strategic Management Journal, 21(4), 455-472.

Ting, I. W. K., \& Lean, H. H. (2009). Intellectual capital performance of financial institutions in Malaysia. Journal of Intellectual Capital, 10(4), 588-599. http://doi.org/10.1108/14691930910996661

Vijayakumaran, R. (2019). Efficiency of working capital management and firm value: evidence from Chinese listed firms. International Journal of Financial Research, 10(6), 133-144. https://doi.org/10.5430/ijfr.v10n6p133

Wu, M., \& Wu, Z. (2018). Empirical assessment of factors influencing corporate performance of China's independent brand automobile companies. International Journal of Financial Research, 9(2), 96-104. https://doi.org/10.5430/ijfr.v9n2p96

Zeitun, R., \& Tian, G. G. (2007). Does ownership affect a firm's performance and default risk in Jordan?. Corporate Governance: The International Journal of Business in Society, 7(1), 66-82. http://doi.org/10.1108/14720700710727122 